\title{
Different levels of supplied energy for lactating cows affect physicochemical attributes of milk
}

\author{
A.M. Gabbi', C.M. McManus' ${ }^{2}$, L.T. Marques ${ }^{3}$, A.S. Abreu ${ }^{4}$, S.C. Machado 5 , M.B. Zanela ${ }^{6}$, \\ R.S. Barbosa ${ }^{7}$ and V. Fischer ${ }^{1,8}$ \\ ${ }^{1}$ Federal University of Rio Grande do Sul, Faculty of Agronomy, Department of Animal Science, \\ Porto Alegre, 91540-000, RS, Brazil \\ ${ }^{2}$ University of Brasília, Institute of Biological Sciences, Brasília, 70910-900, DF, Brazil \\ ${ }^{3}$ Federal University of Pelotas, Pelotas, 96010-610, RS, Brazil \\ ${ }^{4}$ Riograndense Higher Education Center (CESURG), Sarandi, 99560-000, RS, Brazil \\ ${ }^{5}$ Faculties of Itapiranga, Itapiranga, 89896-000, SC, Brazil \\ ${ }^{6}$ Brazilian Agricultural Research Corporation EmbrapaTemperate Climate National Centre, Pelotas, 96010-971, RS, Brazil \\ ${ }^{7}$ Brazilian Agricultural Research Corporation Embrapa Semi-arid, Petrolina, 56302-970, PE, Brazil
}

KEY WORDS: dairy cows, feeding, milk composition, ethanol stability, total digestible nutrients, factor analysis

Received: $\quad 26$ April 2016

Revised: $\quad 16$ March 2017

Accepted: 20 February 2018
${ }^{8}$ Corresponding author: e-mail: vfried@portoweb.com.br, vivinha.fischer@hotmail.com

\begin{abstract}
In the period from 2004 to 2011 , seven trials on lactating cows were conducted to evaluate the relationship between the amounts of energy required, and milk production and composition. In total, 392 observations on 132 animals were selected due to different levels of energy intake. The observations were classified into three groups according to the amount of total digestible nutrients (TDN) provided by the diets, i.e. 67,75 and $94 \%$ TDN. Such characteristics as proportion of energy provided in relation to cow requirements, experiment duration, daily milk production, and fat, protein and lactose contents, total solids percentage, somatic cell score, titratable acidity and ethanol stability test were considered. Levels of supplied energy were positively related with milk production, ethanol stability and lactose content. Seven variables were regarded as discriminant between levels of supplied energy, including proportion of provided energy related to cow requirement, duration of the experiments, ethanol stability test and milk production, and explained more than $70 \%$ of the variance among the observations. Milk production increased linearly with the proportion of the supplied energy from 14,16 to $19 \mathrm{~kg} \cdot \mathrm{d}^{-1}$ per cow, while lactose content increased from 4.37 to $4.56 \%$ as the level of TDN attained $93 \%$ of estimated requirements. Milk stability increased from 74.2 to $76.4 \%$ as the level of TDN attained $79 \%$ of estimated requirements. Increased level of the supplied energy related to requirements of lactating cows improved milk yield, milk stability and lactose content.
\end{abstract}

\section{Introduction}

Nutritional requirements for lactating cows can be calculated using different methodologies, such as those existing in the British (ARC), French (UFL) or North American (NRC) systems (Vermorel and Coulon, 1992). On the other hand, lactating cow energy requirements may be expressed as the amount of total digestible nutrients (TDN), which is still widely used since it can be easily determined by feed analysis (Weiss, 1998).

Decreasing levels of supplied energy imply changes in milk production (Reid et al., 2015), chemical composition (Sova et al., 2014), body weight and 
body condition score (Weber et al., 2015). However, the effect of such reductions on the physical characteristics, in particular ethanol stability, has not been studied extensively. Moreover, the impact of restoring levels of supplied energy on milk chemical and physical attributes is also not precisely documented (Gross et al., 2011).

It is known that changes in the supplied energy intake affect yield and physicochemical composition of milk and may vary according to the productive potential of each cow, stage of lactation, and duration of the feed supply. The multivariate analysis (Macciotta et al., 2012) can be used to assess the relationship between these attributes and their effects on milk properties.

So, the aim of the study was to evaluate the changes in daily milk production and in physicochemical characteristics of milk from lactating cows fed diets with different levels of supplied energy.

\section{Material and methods}

Seven experiments to study the effects of energy intake on productive and milk traits were conducted in the south region of Brazil in Pelotas, RS (30-32 ${ }^{\circ} \mathrm{S}$ latitude and $51-53^{\circ} \mathrm{W}$ longitude). The region is classified according to Cfa climate classification as hot summer and moderate cold winter with annual rainfall near 800 to $1200 \mathrm{~mm}$ and low altitude (below $100 \mathrm{msnm}$ ). The studies were performed from 2004 to 2011 by the researchers from the Centre for Research of Dairy Cattle and Animal Behaviour (NUPLAC), Federal University of Rio Grande do Sul (UFRGS), Federal University of Pelotas (UFPEL) and Brazilian Agricultural Research Corporation (Embrapa). In total, 132 cows in different lactation stages were used in the studies. The data analysis comprises 392 observations selected due to the different levels of energy intake, similar research protocols used and the same variables studied. Each feeding trial is described in detail in Table 1.

All animal procedures were approved by the respective Ethic Committee of each university or research centre under the following protocol numbers 11315, 520042/99-9 and 50405056.

Raw data from experiments were tabulated and included the original variables: levels of supplied energy ( $\%$ TDN), period of feeding (number of days), breed (after transformation of qualitative data to numeric data: $1-$ Jersey, $2-$ Holstein $\times$ Jersey, 3 -Holstein), daily milk production, fat, protein and lactose contents, total solids percentage (TS), somatic cell score (SCS), titratable acidity and ethanol test stability, measured as the lowest concentration of ethanol in alcoholic solution needed to promote the milk coagulation. The higher the ethanol concentration needed, the higher the milk stability.

Data obtained in the experiments were submitted to the multivariate statistical analysis. Observations were standardized for mean equal zero and standard deviation equal to 1 and submitted to the analysis of the principal factors (PROC FACTOR) to investigate the covariation between attributes considering three factors, those with eigenvalues equal or greater than 1, using alpha method as extraction factor. Data were grouped into clusters which were not ranked hierarchically (PROC CLUSTER) and further they were related to the original variables (PROC CANDISC). To determinate the most important variables in the clusterization PROC STEPDISC was used, with level of significance for average square of canonical correlation (ASCC) of $P<0.0001$. The original variables with the greatest contribution in variance within each group with the same level of supplied energy were determined by PROC VARCLUS. Comparison of means among clusters was performed with multivariate analysis (MANOVA), using PROC GLM, which are compared with the Tukey's test with 5\% significance. All statistical procedures were performed using the statistical software SAS 9.3 (SAS Institute Inc., Cary, NC, USA).

\section{Results}

The first principal factor explained $54.9 \%$ of the variance of the attributes and it was mainly related to the protein, fat and total solids contents, while the second principal factor, which explained $32.3 \%$ of the variance, was more related to the levels of supplied energy, milk production and milk stability to ethanol. A negative association between protein, fat and total solids contents with milk yield and proportion of Holstein alleles was observed. Whereas little or no association between these milk components with the levels of supplied energy, percentage of ethanol needed to coagulate the milk, lactose content and milk yield was found. On the other hand, levels of supplied energy were positively associated with milk yield, milk stability and lactose content. The duration of the experiments negatively affected the contents of fat, protein and total solids, but its positive association with milk production, lactose content and milk stability was noticed (Figure 1).

In total, 392 observations on 132 cows were grouped into three clusters, with 115, 135 and 142 observations. As the data were not previously 


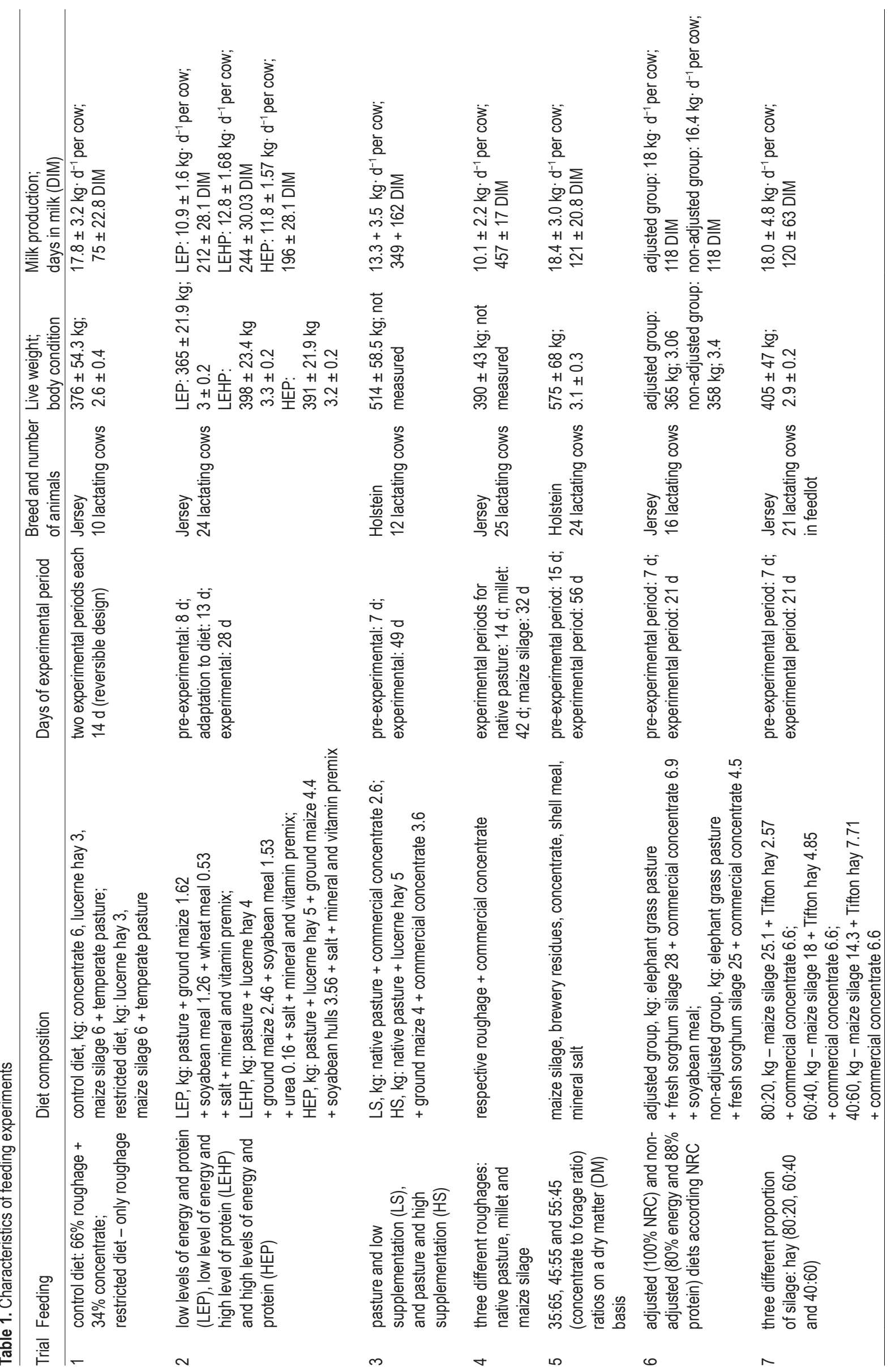




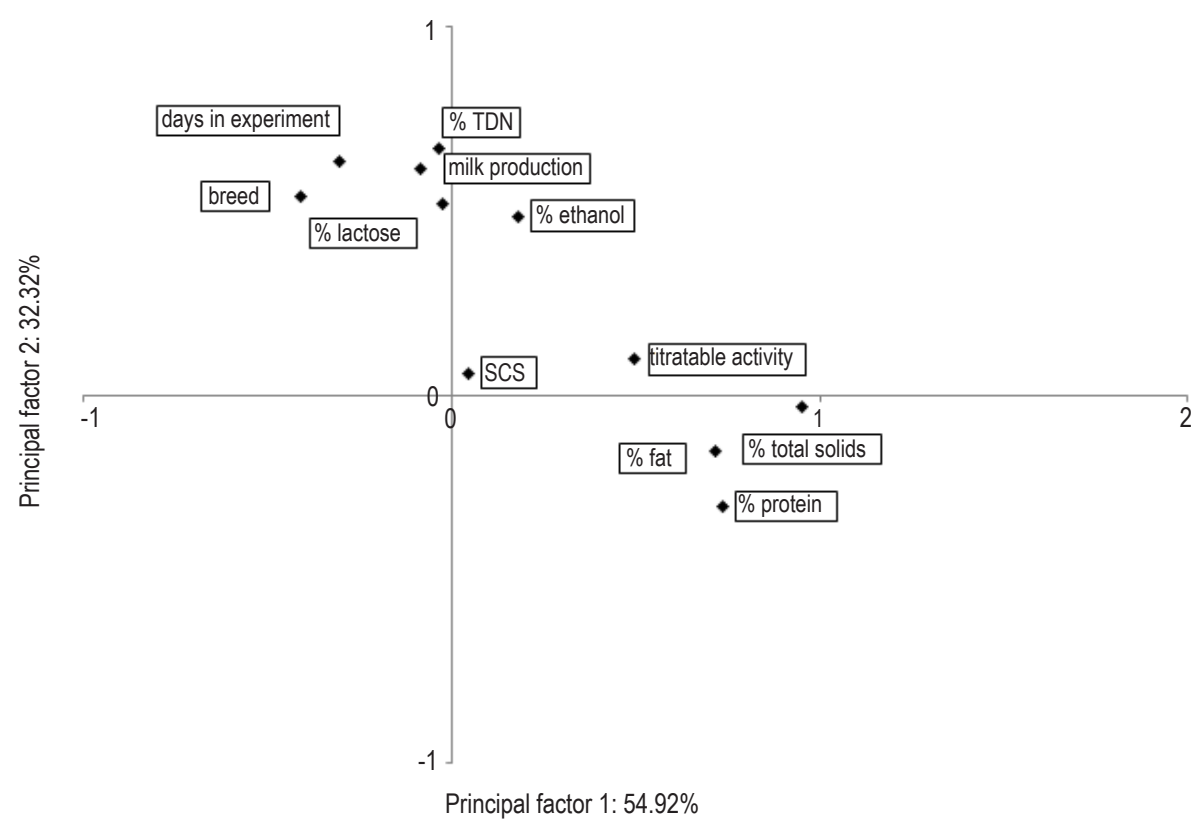

Figure 1. Variables (level of supplied energy, duration of the experiment, milk production and physicochemical characteristics) projected in principal factors 1 and 2

ranked, clustering of the observations was made by similarity between observations and three different levels of TDN found by cluster analysis. The values of canonical correlation ( 0.89 for canonical correlation 1 (Can 1) and 0.77 for canonical correlation 2 (Can 2)) showed a good separation of observations based on the level of supplied energy. In the canonical analysis it was found that such attributes as milk production, lactose content, ethanol stability and duration of the experiments were closely associated with observations of cluster 3 , while such remaining variables as titratable acidity, SCS, protein and fat contents were more associated with the cluster 2 (Figure 2). Amongst 11 variables, seven were considered as discriminant to the formation of three clusters, being the most relevant, according the partial $\mathrm{R}^{2}$ values, the level of energy supply, total solids content and titratable acidity of milk (Table 2). Distinct original variables explained the variance between observations within clusters.

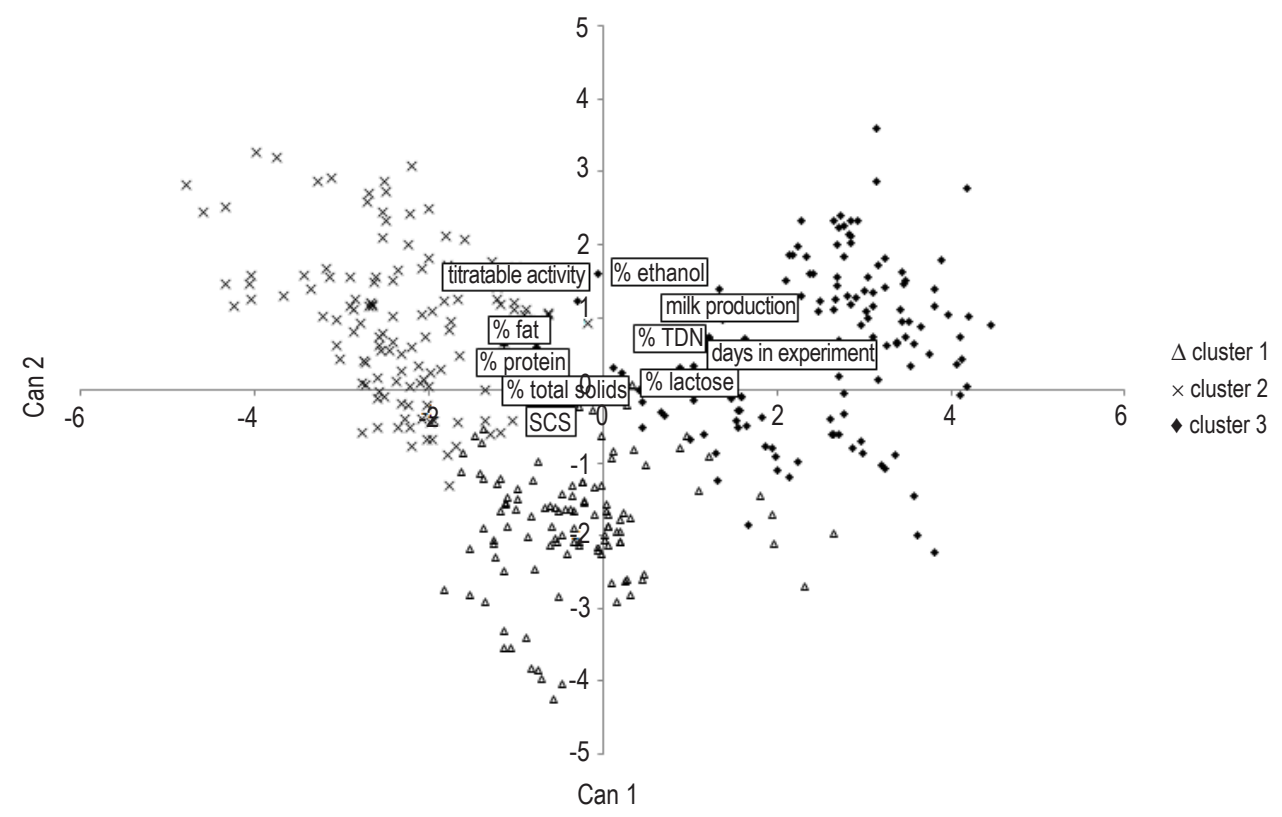

Figure 2. Standardized canonical means of productive attributes and physicochemical characteristics of milk from cows fed different levels of energy 
Table 2. Discriminant analysis of variables selected for the classification of observations according to level of supplied energy

\begin{tabular}{llll}
\hline Indices & Partial- $\mathrm{R}^{2}$ & $P>\mathrm{F}$ & $P>$ ASCC \\
\hline TDN level & 0.901 & $<0.0001$ & $<0.0001$ \\
Total solids content & 0.541 & $<0.0001$ & $<0.0001$ \\
Titratable acidity & 0.178 & $<0.0001$ & $<0.0001$ \\
Milk ethanol stability & 0.092 & $<0.0001$ & $<0.0001$ \\
Protein content & 0.086 & 0.0001 & $<0.0001$ \\
Milk production & 0.045 & 0.0094 & $<0.0001$ \\
Duration of experiment & 0.038 & 0.0201 & $<0.0001$ \\
\hline
\end{tabular}

Partial- $R^{2}$ - coefficient of partial determination; $F$ - F statistic test; ASCC - average square of canonical correlation; TDN - total digestible nutrients
Table 3. Proportion of variance explained by the original variables within each level of supplied energy

\begin{tabular}{lll}
\hline Cluster & Original variable & $\begin{array}{l}\text { Proportion } \\
\text { of variance explained } \\
\text { by variable, \% }\end{array}$ \\
\hline 1 & $\begin{array}{l}\text { TDN level, ethanol stability, milk } \\
\text { production and SCS }\end{array}$ & 71.2 \\
2 & $\begin{array}{l}\text { Fat, lactose and total solids content } \\
3\end{array}$ & 65.9 \\
Duration of trials, titratable acidity & 55.9 \\
and protein content
\end{tabular}

SCS - somatic cells score, calculated as [ $\log _{2}($ SCC / 100000$\left.)+3\right]$; SCC - somatic cells count; TDN - total digestible nutrients

Table 4. Means of productive and milk traits of cows receiving different levels of energy

\begin{tabular}{lccccc}
\hline Indices & Cluster 1 $(n=115)$ & Cluster 2 $(n=135)$ & Cluster 3 $(n=142)$ & RMSE value & $P$-value \\
\hline TDN level, \% & $66.9^{\mathrm{a}}$ & $79.4^{\mathrm{b}}$ & $93.9^{\mathrm{c}}$ & 0.79 & $<0.0001$ \\
Breed of cows ${ }^{1}$ & $1.00^{\mathrm{a}}$ & $1.03^{\mathrm{a}}$ & $2.86^{\mathrm{b}}$ & 0.97 & $<0.0001$ \\
Duration of experiment, days & $28.6^{\mathrm{a}}$ & $28.6^{\mathrm{a}}$ & $48^{\mathrm{b}}$ & 0.81 & $<0.0001$ \\
Days in milk & $168^{\mathrm{a}}$ & $241^{\mathrm{b}}$ & $235^{\mathrm{b}}$ & 0.73 & 0.0001 \\
Milk production, $\mathrm{kg} \cdot \mathrm{d}^{-1}$ per cow & $14^{\mathrm{a}}$ & $16.6^{\mathrm{b}}$ & $19.8^{\mathrm{c}}$ & 0.74 & $<0.0001$ \\
Milk stability, \% ethanol & $74.2^{\mathrm{a}}$ & $76.4^{\mathrm{b}}$ & $76.8^{\mathrm{b}}$ & 0.90 & 0.0001 \\
Titratable acidity, ${ }^{\circ} \mathrm{D}$ & $16.5^{\mathrm{a}}$ & $19.1^{\mathrm{c}}$ & $17.1^{\mathrm{b}}$ & 0.94 & 0.0001 \\
SCS & 3.37 & 3.70 & 3.35 & 0.96 & 0.1807 \\
Milk composition, \% & & & & & $<0.0001$ \\
$\quad$ fat & $3.68^{\mathrm{a}}$ & $5.03^{\mathrm{b}}$ & $3.58^{\mathrm{a}}$ & 0.87 & $<0.0001$ \\
$\quad$ protein & $3.36^{\mathrm{a}}$ & $3.94^{\mathrm{b}}$ & $3.19^{\mathrm{c}}$ & 0.90 & $<0.0001$ \\
$\quad$ lactose & $4.44^{\mathrm{a}}$ & $4.37^{\mathrm{a}}$ & $4.56^{\mathrm{b}}$ & 0.94 & $<0.0001$ \\
$\quad$ total solids & $12.3^{\mathrm{a}}$ & $14.2^{\mathrm{b}}$ & $12.3^{\mathrm{a}}$ & 0.90 & \\
\hline
\end{tabular}

1 Jersey $=1$, Jersey $\times$ Holstein crossbred $=2$, Holstein $=3$; RMSE - root mean square error; TDN - total digestible nutrients; SCS - somatic cells score, calculated as [ $\log _{2}($ SCC / 100000$)+3$ ]; SCC - somatic cells count; abc - values with different superscripts within each row are significantly different (Tukey's test)

The most important attributes explaining the variance between observations were level of supplied energy, milk stability, milk yield and SCS; fat, lactose and total solids content; and duration of the trials, acidity and protein content for clusters 1,2 and 3 , respectively (Table 3 ).

The formation of three different groups according the level of supplied energy was possible due to the cluster analysis. Clusters 1,2 and 3 showed overall means of 67,75 and $94 \%$ provision of TDN requirements and they comprised observations within the range of 55-100, 60-100 and $80-105 \%$ provision of TDN requirements allowing to group observations into low, medium and high level of TDN supply, respectively. The daily milk production increased with the supplementation of TDN to the animals. Milk presented higher stability when TDN levels were supplied within a medium and high range. The means of the original variables for each of the three clusters are shown in Table 4.

\section{Discussion}

The increase in the nutrient supply results in higher nutrient availability to the mammary gland (Lemosquet et al., 2009a). The most noticeable is glucose, the precursor of lactose, which is the primary osmotic regulator of milk volume (Lemosquet et al., 2009b; Wall and McFadden, 2012). In the present study, higher level of supplied energy resulted in higher milk yield and lactose content.

Samples ranked as low level of supplied energy were taken from grazing cows or those fed silage with low to moderate addition of concentrates. Medium and high energy supply groups received at least roughage to concentrate proportion of approximately 60 to 40 , with feeds of good quality. Energy supply is usually augmented by the inclusion of high quality forage with high digestibility or inclusion of concentrate into diet, resulting in higher concentrate to roughage ratio, which is a well-known and widespread tool to enhance milk yield (Whelan et al., 2012). 
Feeding systems supplying similar energy levels as those described in the present study are characterised by an inverse association between stocking rate, milk yield and lactose content, but only under assumption that the low stocking rate allows to increase energy intake through selection of the highly digestible plants (McCarthy et al., 2013). However, the increase in the energy supply does not always affect milk physicochemical composition (Giallongo et al., 2015), and this relation is dependent on the original energy level, productive potential of cow, lactation stage and net increment of supplied energy (Benchaar et al., 2014; Boerman et al., 2015; Broderick et al., 2015).

The difference in milk protein content between clusters 1 and 2 has the same magnitude as the increase in milk production. Once both groups have similar proportion of animals of the same breed (Jersey), it can be speculated that this increment was possible due to the increase in the amount of metabolites necessary for protein synthesis, especially glucose precursors and amino-acids, probably because of larger amount of concentrate supplied. Increased amounts of rumen digestible carbohydrates, especially of starch, increased the protein content in milk (Lohrenz et al., 2010; Boerman et al., 2015).

High level of supplied energy supplemented as starch results in greater milk production and milk protein synthesis, which is attributed to increased secretion of insulin and insulin growth factor 1 (Rius et al., 2010). However, a reduction of milk protein content observed in the cluster 3 with higher energy supply can be partly explained by the dilution effect that increased the volume of milk by $40 \%$, as well as by a higher proportion of Holstein cows in this cluster in comparison to the predominance of Jersey cows in groups 1 and 2.

The higher milk fat content observed in the cluster 2 than in the cluster 3, may have resulted from the greater use of roughage, which in turn increased the diet fibre content. In this cluster the predominance of Jersey cows was negligible. Xue et al. (2011), however observed that JerseyHolstein crossbred cows fed either low (30\%) or high $(70 \%)$ contents of grass silage produced milk with high fat content. On the other hand, the low value of milk fat content observed in the cluster 1 , albeit statistically similar to the cluster 3 , was contradictory to our expectations. It was hypothesised that milk fat content in the group predominantly composed of Jersey cows, with an average of 168 days in milk and fed diets with about $65 \%$ of roughage should have been high.
The lack of relationship between the level of supplied energy with SCS is in agreement with results presented by Moyes et al. (2009) and Vance et al. (2012), who found no relation among energy deficit and characteristics of the immune system.

The improved milk stability in the ethanol test (with higher levels of nutritional supply) have been reported when diets with a low percentage of fibre (Barchiesi-Ferrari et al., 2007) or high overall nutrient supply (Fruscalso et al., 2013) were fed to animals, albeit in the latter just two diets $(50 \%$ of feed restriction and with no restriction) were evaluated. The integrity of the tight junctions of mammary epithelial cells is disturbed by nutrient deprivation (Stumpf et al., 2013) and it is associated with lower lactose content but higher concentrations of sodium and chloride in milk (Chavez et al., 2004; Stumpf et al., 2013). In the present study, the measured attributes in milk do not allow to investigate the mechanism of action of the increasing energy supply on milk stability.

\section{Conclusions}

Increasing level of supplied energy to dairy cows improves milk yield, lactose content and milk stability in the ethanol test, but does not influence other milk traits or the health of the udder. The usage of the high level of supplied energy can be advantageous for farmers to whom dairy industry offers a better payment for better milk quality.

\section{References}

Barchiesi-Ferrari C.G., Williams-Salinas P.A., Salvo-Garrido S.I., 2007. Milk instability associated with milk composition and seasonal lactation in grazing dairy cows (in Spanish). Pesqui. Agropecu. Bras. 42, 1785-1791, https://doi.org/10.1590/ S0100-204X2007001200017

Benchaar C., McAllister T.A., Petit H.V., Chouinard P.Y., 2014. Whole flax seed and flax oil supplementation of dairy cows fed highforage or high-concentrate diets: Effects on digestion, ruminal fermentation characteristics, protozoal populations and milk fatty acid profile. Anim. Feed Sci. Technol. 198, 117-129, https://doi.org/10.1016/j.anifeedsci.2014.10.003

Boerman J.P., Potts S.B., VandeHaar M.J., Allen M.S., Lock A.L., 2015. Milk production responses to a change in dietary starch concentration vary by production level in dairy cattle. J. Dairy Sci. 98, 4698-4706, https://doi.org/10.3168/jds.2014-8999

Broderick G.A., Faciola A.P., Armentano L.E., 2015. Replacing dietary soybean meal with canola meal improves production and efficiency of lactating dairy cows. J. Dairy Sci. 98, 5672-5687, https://doi.org/10.3168/jds.2015-9563

Chavez M.S., Negri L.M., Taverna M.A., Cuatrín A., 2004. Bovine milk composition parameters affecting the ethanol stability. J. Dairy Res. 71, 201-206, https://doi.org/10.1017/ S0022029904000172 
Fruscalso V., Stumpf M.T., McManus C.M., Fischer V., 2013. Feeding restriction impairs milk yield and physicochemical properties rendering it less suitable for sale. Sci. Agric. 70, 237-241, https://doi.org/10.1590/S0103-90162013000400003

Giallongo F., Oh J., Frederick T., Isenberg B., Kniffen D.M., Fabin R.A., Hristov A.N., 2015. Extruded soybean meal increased feed intake and milk production in dairy cows. J. Dairy Sci. 98, 6471-6485, https://doi.org/10.3168/jds.2015-9786

Gross J., van Dorland H.A., Bruckmaier R.M., Schwarz F.J., 2011. Performance and metabolic profile of dairy cows during a lactational and deliberately induced negative energy balance with subsequent realimentation. J. Dairy Sci. 94 1820-1830, https://doi.org/10.3168/jds.2010-3707

Lemosquet S., Delamaire E., Lapierre H., Blum J.W., Peyraudl J.L., 2009a. Effects of glucose, propionic acid, and nonessential amino acids on glucose metabolism and milk yield in Holstein dairy cows. J. Dairy Sci. 92, 3244-3257, https://doi. org/10.3168/jds.2008-1610

Lemosquet S., Raggio G., Lobley G.E., Rulquin H., Guinard-Flament J., Lapierre H., 2009b. Whole-body glucose metabolism and mammary energetic nutrient metabolism in lactating dairy cows receiving digestive infusions of casein and propionic acid. J. Dairy Sci. 92, 6068-6082, https://doi.org/10.3168/ jds.2009-2018

Lohrenz A.-K., Duske K., Schneider F., Nürnberg K., Losand B., Seyfert H.M., Metges C.C., Hammon H.M., 2010. Milk performance and glucose metabolism in dairy cows fed rumen-protected fat during mid lactation. J. Dairy Sci. 93, 5867-5876, https://doi.org/10.3168/jds.2010-3342

Macciotta N.P.P., Cecchinato A., Mele M., Bittante G., 2012. Use of multivariate factor analysis to define new indicator variables for milk composition and coagulation properties in Brown Swiss cows. J. Dairy Sci. 95, 7346-7354, https://doi. org/10.3168/jds.2012-5546

McCarthy B., Delaby L., Pierce K.M., Brennan A., Horan B., 2013. The effect of stocking rate and calving date on milk production of Holstein-Friesian dairy cows. Livest. Sci. 153, 123-134, https://doi.org/10.1016/j.livsci.2013.01.013

Moyes K.M., Drackley J.K., Salak-Johnson J.L., Morin D.E., Hope J.C., Loor J.J., 2009. Dietary-induced negative energy balance has minimal effects on innate immunity during a Streptococcus uberis mastitis challenge in dairy cows during midlactation J. Dairy Sci. 92, 4301-4316, https://doi.org/10.3168/jds.20092170

Reid M., O'Donovan M., Murphy J.P., Fleming C., Kennedy E., Lewis E., 2015. The effect of high and low levels of supplementation on milk production, nitrogen utilization efficiency, and milk protein fractions in late-lactation dairy cows. J. Dairy Sci. 98 , 5529-5544, https://doi.org/10.3168/jds.2014-9016
Rius A.G., McGilliard M.L., Umberger C.A., Hanigan M.D., 2010. Interactions of energy and predicted metabolizable protein in determining nitrogen efficiency in the lactating dairy cow. J. Dairy Sci. 93, 2034-2043, https://doi.org/10.3168/jds.20081777

Sova A.D., LeBlanc S.J., McBride B.W., DeVries T.J., 2014. Accuracy and precision of total mixed rations fed on commercial dairy farms. J. Dairy Sci. 97, 562-571, https://doi.org/10.3168/ jds.2013-6951

Stumpf M.T., Fischer V., McManus C.M., Kolling G.J., Zanela M.B., Santos C.S., Abreu A.S., Montagner P., 2013. Severe feed restriction increases permeability of mammary gland cell tight junctions and reduces ethanol stability of milk. Animal 7, 1137-1142, https://doi.org/10.1017/S1751731113000128

Vance E.R., Ferris C.P., Elliott C.T., Kilpatrick D.J., 2012. A comparison of the feeding and grazing behaviour of primiparous HolsteinFriesian and JerseyxHolstein-Friesian dairy cows. Irish J. Agric. Food Res. 51, 45-61

Vermorel M., Coulon J.-B., 1992. Dairy cow feeding: comparison of energy feeding systems (in French). INRA Prod. Anim. 5, 289-298

Xue B., Yan T., Ferris C.F., Mayne C.S., 2011. Milk production and energy efficiency of Holstein and Jersey-Holstein crossbred dairy cows offered diets containing grass silage. J. Dairy Sci. 94, 1455-1464, https://doi.org/10.3168/jds.2010-3663

Wall E.H., McFadden T.B., 2012. A local affair: How the mammary gland adapts to changes in milking frequency. J. Anim. Sci. 90, 1695-1707, https://doi.org/10.2527/jas.2011-4790

Weber C., Losand B., Tuchscherer A., Rehbock F., Blum E., Yang W. Bruckmaier R.M., Sanftleben P., Hammon H.M., 2015. Effects of dry period length on milk production, body condition, metabolites, and hepatic glucose metabolism in dairy cows. J. Dairy Sci. 98, 1772-1785, https://doi.org/10.3168/jds.20148598

Weiss W.P., 1998. Estimating the available energy content of feeds for dairy cattle. J. Dairy Sci. 81, 830-839, https://doi.org/10.3168/ jds.S0022-0302(98)75641-3

Whelan S.J., Pierce K.M., Flynn B., Mulligan F.J., 2012. Effect of supplemental concentrate type on milk production and metabolic status in early-lactation dairy cows grazing perennial ryegrass-based pasture. J. Dairy Sci. 95, 4541-4549, https:// doi.org/10.3168/jds.2011-5292 